\title{
Black-throated Blue Warbler in Sask.
}

\author{
By DR. R. W. NERO
}

The remarkable influence of the Audubon Society was well demonstrated recently when the executive director of the Canadian Society, Mr. John A. Livingston, visited Regina. On October 16, while visiting Moose Jaw with Dr. George Ledingham, Mr. Livingston saw a small bird fly against a window pane. Upon inspection and later preparation as a study skin this bird was found to be an immature female Blackthroated Blue Warbler (Dendroica caerulescens). This is, so far as I have been able to determine, the second known specimen for the province. The first one, an adult male, was collected at Percival, Saskatchewan, on October 21, 1936 by John and Robert Nelson. It was forwarded to the museum by $\mathrm{Mr}$. E. M. Callin and has been preserved as a mounted specimen. This latter record has been mentioned by Potter (1943: 71) and Bent (1953: 234).

The Black-throated Blue Warbler is a common bird of the eastern deciduous woodlands but it is rare even in Manitoba. Bent (op. cit.) suggested that it might be extending its range westward, breeding rarely in Manitoba or Saskatchewan. Movat (1947: 113) reported some sight observations of this species in June and July, 1939, at Emma Lake, and Potter (loc. cit.) observed a male at Eastend on September 21, 1937. It was not found, however, in the Flotten Lake region (Godfrey, 1950), the Somme district (R. \& T. Hooper, 1954), or at Nipawin (Street, 1943), areas which are all within the Canadian Zone in which this species nests. A breeding record in Saskatchewan of this striking little bird would be an exciting discovery.

BENT, A. C. - 1953 - Lifa Histories of North American Wood Warblers. Bull. 203. 734 pp. GODFREY, W. E. - 1950 - Birds of the Cypress Hills and Flotten Lake Regions, Saskatchewan. Nat'l Mus. Can. Bull. 120. 96 pp.

HOOPER, R. and HOOPER, D. - 1954 - A Preliminary List of the Birds of the Somme district, Saskatchewan. Contribution No. 3 of the Yorkton Nat. Hist. Soc. 13 pp.

HOUSTON, C. S. - 1949 - The Birds of the Yorkton district, Saskatchewan. Can. Field-Nat., $63(6): 215-241$.

MOWAT, F. M. - 1947 - Notes on the Birds of Emma Lake. Saskatchewan. Can. Field-Nat., 61 (3): $105-115$.

POTTER, L.B. - 1943 - Bird notes from south-western Saskatchewan. Can. Field-Nat., $57(4$ and 5$): 69-72$.

STREET, M. G. - 1943 - A list of the birds of Nipawin, Saskatchewan. Contribution No. 2 of the Yorkton Nat. Hist. Soc. 9 pp.

\section{The Kangaroo Rat in Saskatchewan}

\author{
By DR. R. W. NERO
}

The Kangaroo Rat is a small, light reddish-brown mammal, white underneath and with a white stripe across each flank. The most striking features of the Kangaroo Rat are the greatly enlarged hind legs and feet which, together with the long tail, represent adaptations for a bipedal leaping or bounding gait. It derives the first part of its name from its similarity in this respect to the true Kangaroos. Just as the Prairie Dog is not a dog, the Kangaroo Rat is not a member of the rat tribe but belongs to a group of native mice distinguished by the presence of external, fur-lined cheek pouches in which it can carry large quantities of food. The species found in this province is about the size of a small ground-squirrel. The most recent one captured was $103 / 4$ inches long from the tip of its nose to the end of its tail; however, $53 / 4$ inches of this length consisted of the tail alone. This mammal is so well adapted to dry areas, according to E. T. Seton, that instead of drinking, it obtains water only through eating succulent roots.

The Kangaroo Rat is usually regarded a.s a mammal of the desertlike regions of North America, but it has been known to occur in Saskatchewan since 1933. (Its only other occurrence in Canada is based on a 
single specimen from southeastern Alberta.) Only two specimens have been reported in the province during the last 22 years, but since it is completely nocturnal it may be more common than these few records suggest. The first one known to have been found in Saskatchewan was captured by a dog in 1933 at Shackleton. The following year a second cne was found dead on a road near Tompkins (Anderson, 1946, Catalogue of Canadian Recent Mammals). In July, the first week of 1955 , a third cne was obtained by $\mathrm{Mr}$ Michael Spies near Portreeve. A glance at a map shows that these three records of this interesting mammal fall within a circle 55 miles in diameter. in the southwest corner of the province, about 40 miles west of Swift Current. This particular species, the Ord Kangaroo Rat (Dipodomys ordii) is widely distributed over the western United States. It is reasonable to expect, therefore, that additional work will reveal the presence of Kangaroo Rats in suitable areas from Portreeve south to the border of the province. Determination of the range of this species within the province. as well as that of other mammals, is one of the important prcblems which still need to be solved. Since Kangaroo Rats live in colonies and erect large mounds of earth pierced by numerous openings they shculd not be too difficult to locate.

\section{Commensal Feeding of Muskrat and Rusty Blackbird}

\author{
By DR. R. W. NERO
}

In the dictionary commensal behavior is defined as "eating at the same table." In biology this term has been used to designate a kind of parasitism in which, however, the "host" neither loses nor gains. On November 5, 1955, I observed a good example of commensalism between a Rusty Blackbird (Euphagus carolinus) and a Muskrat (Ondatra zibethica) while hunting along the Qu'Appelle River north of Regina. Although it was cold, the temperature during the day being 15 to 20 degrees $F$. with a brisk wind blow- ing from the Northwest, the river was still open in places, a thin layer of ice extending up to 10 feet from each shore. Early in the afternoon I had several times noticed Muskrats sitting on the edge of the ice and eating. On two or three occasions a Rusty Blackbird was observed near a "rat", but since I was fresh and intent on the hunt, little attention was paid to either bird or mammal. Pacsing by the same general area later in the afternoon, being somewhat wearied and more inclined to pause occasionally, I stopped to watch a Rusty Blackbird which was moving about on the ice on the opposite shore near a rat. The latter was feeding on some dark vegetation which it had evidently just brought up from the stream bottom. As I watched, the Blackbird moved in to within 5 or 6 inches of the rat and began warily picking at the vegetation, jumping back each time the latter raised its head in an obviously aggressive gesture. The Blackbird continued to feed in a cautious manner for 2 or 3 minutes, before $I$ left. It seemed quite clear that the Blackbird was feeding on animal life which had been brought up with the vegetation, presumably crustaceans or other arthropods, or possibly snails. I am convinced that the Rusties which I had seen earlier in the afterncon were dining at the same kind cf table.

Commensal feeding involving another icterid was reported by Shelley in 1930 (Companionate feeding activities of a Spotted Sandpiper and a Red-winged Blackbird. Auk, 47 (1): 78-79). A Spotted Sandpiper (Actitis macularia), feeding on bottom-feeding larvae of the caddis-fly which it brought to shore to eat, was closely followed by a Redwing (Agelaius phoeniceus), which quickly ate the larvae which the Sandpiper occasionally discarded.

\section{Rattlesnake dens along the South} Saskatchewan River. - Mr. J. J. Deck of Mendham reports that dens of Rattlesnakes are numerous along the river hills on the north side of the Saskatchewan River near the Alberta boundary. Mr. Deck loaned to the Museum, for viewing, a film he had made showing the "rattlers" in this area. 